\title{
In Memoriam: Gabriel Ward Lasker (April 29, 1912-August 27, 2002)
}

\author{
Barry Bogin*
}

Department of Behavioral Sciences, University of Michigan-Dearborn, Dearborn, Michigan 48128-1491

Gabriel W. Lasker died on August 27, 2002 from complications of kidney disease. He was 90 years old. Lasker was one of the leading figures in anthropology after World War II. He helped create the population approach in biological anthropology, which rejected concepts of fixed racial typology in favor of variation and plasticity in adaptation. $\mathrm{He}$ developed the methodology of using family surnames in studies of human genetics and migration. Lasker served the profession as the editor of major journals and books and as an officer in its societies.

Born in England, Lasker came to the United States with his family in 1916. His early education was in various progressive private schools. After attending the University of Wisconsin Experimental College for 2 years, he transferred to the University of Michigan, where he graduated with a B.A. in 1934 , but without any major or any coursework in anthropology. He did some research with his mother (Margaret Naomi Ward Lasker, a biochemist) and published his first paper with her in Human Biology in 1936. Because of the Depression, he was unable to find regular employment. He did find a job in China, where he lived for 2 years (1934-1936), teaching English to Chinese railroad workers at Chian T'ung University in Peking (now Beijing) and studying the Chinese language. In an autobiographical note published in a special issue of Human Biology in 1982, Lasker explains that his father led him to China. Bruno Lasker (a prominent social scientist with expertise in Asia) advised his son that "anyone who knew Chinese could always have a job." While in China, several contacts with faculty at the American Medical College of Peking led the younger Lasker to an interest in physical anthropology. With support of those faculty, Lasker applied to Harvard and was accepted into the graduate program. Lasker wrote that since he "never had a course in anthropology I had no bad record in the subject and Ernest Hooton was willing to take me on..." Lasker received his M.A. in 1940 and a Ph.D. in 1945.

The title of his dissertation was Physical Characteristics of Chinese: A Study of Physical Differences and Developments Among Chinese at Home and Abroad. Hooton's approach to physical anthropology represented the then dominant view of human physical "types" and identifiable "races." While writing his thesis, Lasker consulted with Franz Boas and H.L. Shapiro, who advocated the view that human

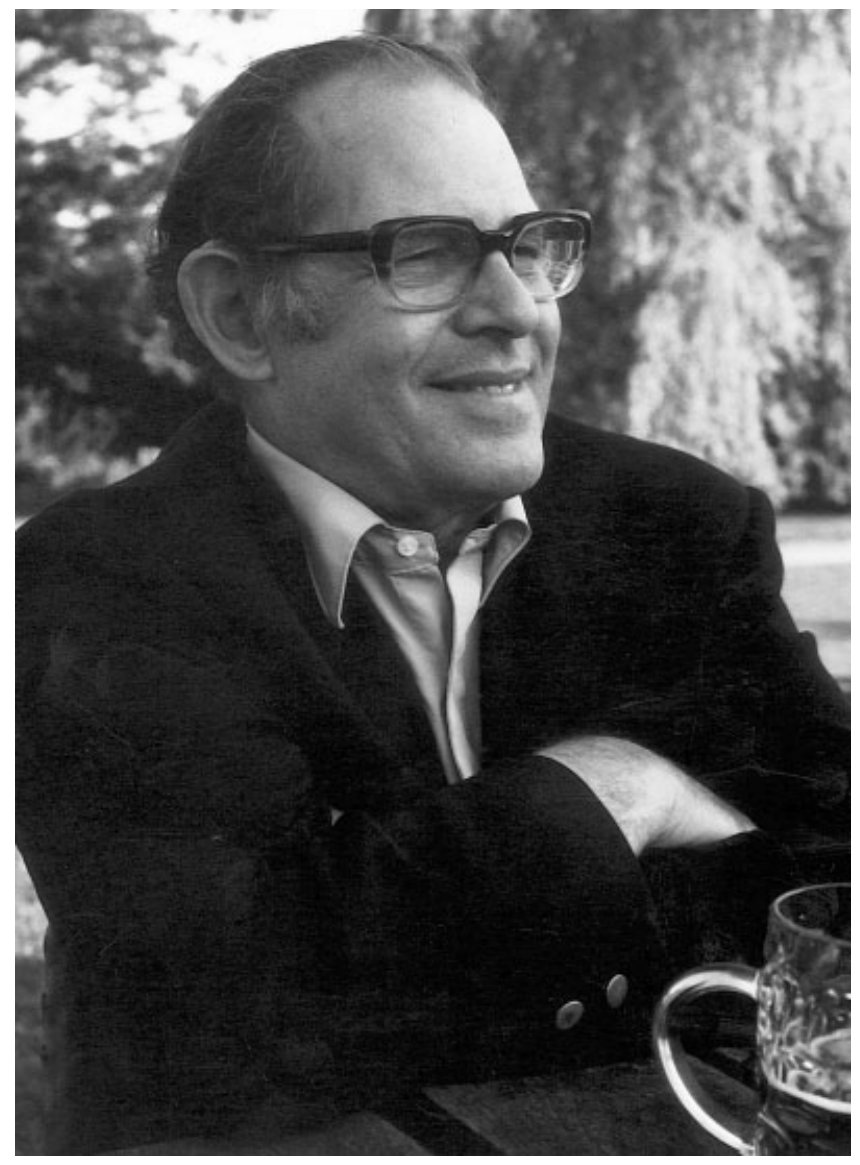

Gabriel Ward Lasker, 1912-2002.

biology and anatomy were plastic. Lasker tried to incorporate both perspectives of human biology in his dissertation, which led Hooton to proclaim that it was "the biggest damn thesis I have ever seen; really two theses (haw, haw, haw); the one I wanted and the one you wanted to write yourself (haw, haw!)."

\footnotetext{
*Correspondence to: Barry Bogin, Department of Behavioral Sciences, University of Michigan-Dearborn, 4901 Evergreen Road, Dearborn, MI 48128-1491.
}

Received and accepted 20 November 2002.

DOI 10.1002/ajpa.10224 
In 1946, he was appointed instructor in anatomy at Wayne State University School of Medicine (Detroit, MI); in 1947, Assistant Professor; in 1955, Associate Professor; and in 1964, Full Professor. Following his retirement as Emeritus Professor in 1982 , he continued to serve his university, his profession, and academic society in his traditional roles as teacher, researcher, and editor. For 36 years, Lasker educated hundreds of medical students, not only in anatomy but also in the methods of scientific inquiry and in the art of scientific writing. Lasker's editorial contributions include founding the Yearbook of Physical Anthropology in 1945 and editing it until 1952. Bernice (Bunny) Kaplan assisted in this project and many others, as Lasker and Kaplan married and sustained professional and personal teamwork for over 50 years. Lasker served for 34 years (1953-1987) as editor of the journal Human Biology. That journal, founded by Raymond Pearl in the $1920 \mathrm{~s}$, was moribund by the early $1950 \mathrm{~s}$, but was saved through the efforts of Lasker and W.W. Howells. The journal became the official publication of the Human Biology Council (now the Human Biology Association), and in 1999 became the official organ of the American Association of Anthropological Genetics. Lasker cofounded the book series Cambridge Studies in Biological and Evolutionary Anthropology in 1985. There are now 33 books published, two in press, and 11 more on the horizon in that collection. He wrote the first book, Surnames and Genetic Structure, published in 1985, which is still selling.

Lasker considered his editorial work to be just as important and to require just as much skill as his teaching and research. One example is the publication in Human Biology of some of the earliest papers by Morris Goodman, on the use of molecular biology in primate systematics. Everyone who has published or read a paper in Human Biology, and that includes just about every human biologist of the past 50 years, benefited from Lasker's commitment and dedication.

In 1978, Lasker invited me to help edit Human Biology, and I did so for a decade. During that time, Lasker became my mentor and friend. I learned from him that high-quality scientific work is done in a social context. In addition to a good hypothesis, one needs to act with grace and kindness toward others in the field. Lasker showed me that it was "okay" to think differently than others, but only if I was prepared to work hard and work honestly to defend my position. The time we spent in his office and at our weekly lunches was highly productive and most enjoyable.

During his career, Lasker influenced dozens of other academics via his service to the profession. He served as Secretary (1945-1949) and President (1963-1965) of the American Association of Physical Anthropologists. He was Secretary (1953-1957) of Section H (Anthropology) of the American Association for the Advancement of Science (AAAS). In that role, Lasker demonstrated his social convictions on the occasion of the 1954 AAAS meetings in Atlanta, Georgia. At that time, hotels were segregated and the meetings were scheduled for a "whites only" hotel. After discussions with Bunny Kaplan, Lasker refused to attend or organize the program for the meeting. In addition, Lasker helped to nominate Dr. Montague Cobb for the chairmanship of Section H. Cobb was Professor of Anatomy at Howard University and the most prominent African American in anthropology at that time. Cobb was elected, but even this did not persuade the AAAS to change the meeting venue. A resolution never to meet again in a city with segregated facilities was presented to the executive council of the AAAS at the Atlanta meeting. After the meeting, the resolution went to a mail ballot to all members and passed decisively. It was reported in the New York Times, and soon afterward, Atlanta hotels were integrated. This occurred before the Civil Rights Movement integrated hotels, restaurants, and other public facilities in other areas of the South. About a decade later, Lasker was elected Vice President of the AAAS and Chairman of Section H (1968-1970). He was also elected president of the Human Biology Council (1982-1984). In those roles, he helped bring anthropological methods and questions to the forefront of American science.

Lasker's published works (which number in the hundreds) cover the major themes of biological anthropology. The subjects of migration, variation, growth, genetics, and demography dominate Lasker's articles, chapters, and books. His single most influential article is probably "Human Biological Adaptability" (Science, 1969). That article provided the operational definitions of human adaptation that are still in use today. In his memoir, Happenings and Hearsay (Savoyard Books, 1999), Lasker wrote that his fieldwork with Bunny Kaplan in Mexico, between 1948-1960, was "the best research I have done." That work was on the biological effects of migration, ethnicity, biochemical genetics, surnames and inbreeding, and reproductive success. Through these projects and additional fieldwork in Peru, Lasker influenced the research agendas of three generations of biological anthropologists.

In addition, he influenced the entire discipline of anthropology by organizing a series of summer seminars in the 1950s. These seminars were supported by the Wenner-Gren Foundation, which was also supporting the Yearbook of Physical Anthropology. Bunny Kaplan wrote accounts of the seminars, and Lasker wrote a summary of the state of physical anthropology for the Yearbook. Sherwood L. Washburn wrote (Human Biology, 1982), "The purpose of the Yearbook and the summer seminars was to accelerate change in physical anthropology and to bring the science to the attention of a much wider range of people. The profession is so large now that it is hard to realize that before the Second World War it was difficult to get enough papers for the 
annual meeting. More people attended the second summer seminar than there were members of the Association!" The summer seminar concept was reprised once in the late 1960s, and many of the students and young professors in attendance are today leaders of biological anthropology.

Lasker's break with 19th century scientific traditions, which began with his dissertation, continued with the Yearbook, the summer seminars, Human Biology, and his research. All of these were designed to create a new emphasis on population biology, genetic variation, and adaptation in physical anthropology, or what Washburn titled the "New Physical Anthropology." Washburn wrote, "Our commitment to change was a continuation of long discussions that began at Harvard." Lasker and Washburn began discussions of a new anthropology in 1938 when both were students at Harvard. The two consulted closely again in 1953 when Lasker spent a quarter at the University of Chicago. Lasker summarized his view of the field in his textbook Physical Anthropology (1973). This was one of the first books to eliminate detailed discussions of "race" classification and instead provide current understandings of genetics and demography.

The story of Gabriel Lasker's life must be set in the broader context of the social, economic, and political changes that occurred during the 20th cen- tury. The enormous upheavals in secular and academic life brought about by these changes certainly played a part in shaping Lasker's career. In turn, Lasker imposed an indelible and enormously beneficial mark on anthropology, biology, and human affairs. In recognition of his achievements, Lasker was inducted into the Wayne State University Academy of Scholars in 1981. He received the Charles R. Darwin Lifetime Achievement Award of the American Association of Physical Anthropologists in 1991 and the Franz Boas award in 1996 from the Human Biology Association. The University of Turin awarded him an honorary Doctor of Science degree in 2000.

Gabriel Lasker is survived by his wife of 53 years, Dr. Bernice (Bunny) Kaplan, Professor Emeritus of Anthropology at Wayne State, and three children: Robert Lasker of Detroit, Edward (Ted) Lasker of Beverly Hills, Michigan, and Anne Lasker of Grand Rapids, Michigan. His only grandchild, Wilson Eduardo Lasker, is 7 years old. ${ }^{1}$

\footnotetext{
${ }^{1}$ Anyone who wishes to send condolences to Bunny may do so at 31339 Pierce St., Beverly Hills, MI 48025-5513. The family asks that donations in lieu of flowers be made to one of the following charities: the Council for a Livable World, Southern Poverty Law Center, Union of Concerned Scientists, War Resisters League, or Ploughshares Fund.
} 